\title{
Negative serosurvey of Toxoplasma gondii antibodies in Golden-headed Lion Tamarin (Leontopithecus chrysomelas) from Niterói/RJ, Brazil
}

\author{
Pesquisa sorológica de anticorpos anti-Toxoplasma gondii em Mico-leão-da-cara-dourada \\ (Leontopithecus chrysomelas) de Niterói/RJ, Brasil \\ Camila Vieira Molina ${ }^{1,2^{*}}$; Felipe da Silva Krawczak ${ }^{3}$; Marina Galvão Bueno ${ }^{2,4}$; Herbert Sousa Soares ${ }^{3}$; \\ Solange Maria Genari ${ }^{3}$; Alcides Pissinatti ${ }^{5,6}$; Maria Cecília Martins Kierulff ${ }^{2,7}$; Tiago Ferreira da Silva ${ }^{2}$; \\ Danilo Gomes de Freitas ${ }^{2}$; Larissa Cristinne Canelii ${ }^{1}$; José Luiz Catão-Dias ${ }^{1}$
}

\author{
${ }^{1}$ Laboratório de Patologia Comparada de Animais Selvagens - LAPCOM, Departamento de Patologia - VPT, Faculdade de Medicina \\ Veterinária e Zootecnia, Universidade de São Paulo - USP, São Paulo, SP, Brasil \\ ${ }^{2}$ Instituto Pri-Matas para a Conservação da Biodiversidade, Belo Horizonte, MG, Brasil \\ ${ }^{3}$ Laboratório de Doenças Parasitárias, Departamento de Medicina Veterinária Preventiva e Saúde Animal - VPS, Faculdade de \\ Medicina Veterinária e Zootecnia, Universidade de São Paulo - USP, São Paulo, SP, Brasil \\ ${ }^{4}$ Programa Institucional Biodiversidade e Saúde, Fundação Oswaldo Cruz - Fiocruz, Rio de Janeiro, RJ, Brasil \\ ${ }^{5}$ Centro de Primatologia do Rio de Janeiro, Instituto Estadual do Ambiente - INEA, Guapimirim, RJ, Brasil \\ ${ }^{6}$ Centro Universitário Serra dos Órgãos, Teresópolis, RJ, Brasil \\ ${ }^{7}$ Programa de Pós-graduação em Biodiversidade Tropical, Universidade Federal do Espírito Santo - UFES, Sáo Mateus, ES, Brasil
}

Received August 3, 2016

Accepted September 21, 2016

\begin{abstract}
New World Nonhuman Primates are highly susceptible to clinical toxoplasmosis. Serum samples from 126 recently captured Leontopithecus chrysomelas, from an exotic and invasive population, were tested for Toxoplasma gondii antibodies by the modified agglutination test (MAT, cut-off 1:25); all were seronegative. The MAT is highly specific and is not species-specific. This is the first report of T. gondii survey in this tamarin in the wild. This result is consistent with prior reports that showed the high susceptibility of the species to infection by $T$. gondii usually with high mortality rates.

Keywords: New World Nonhuman Primates, Callitrichidae, enviornmental health, invasive fauna, exoctic fauna, free-ranging.

\section{Resumo}

Primatas não humanos são extremamente susceptíveis a toxoplasmose. No presente estudo, 126 Leontopithecus chrysomelas foram capturados de uma população de vida livre, exótica e invasora, e amostras de soros foram testadas para a presença de anticorpos anti- Toxoplasma gondii pelo Teste de Aglutinaçáo Modificado (MAT, ponto de corte 1:25). Todos os animais testados foram negativos. O MAT é um teste altamente específico e não é espécie-específico. Esse é o primeiro estudo de pesquisa por anticorpos anti- $T$. gondii nessa espécie em vida livre. $\mathrm{O}$ resultado corrobora com o conhecimento prévio sobre a susceptibilidade dessa espécie a infecção pelo parasite T. gondii.
\end{abstract}

Palavras-chave: Primatas do Novo Mundo, Callitrichidae, saúde ambiental, fauna invasora, fauna exótica, vida livre.

\footnotetext{
*Corresponding author: Camila Vieira Molina. Laboratório de Patologia Comparada de Animais Selvagens - LAPCOM, Departamento de Patologia

- VPT, Faculdade de Medicina Veterinária e Zootecnia - USP, Av. Prof.

Dr. Orlando Marques de Paiva, 87, Cidade Universitária, CEP 05508-270,

São Paulo, SP, Brasil. e-mail: camolina.vet@gmail.com
} 
Leontopithecus chrysomelas is a New World Monkey (NWM) from the Callitrichidae family, which is commonly called the Golden-Headed Lion Tamarin (GHLT), is classified as Endangered (EN) by IUCN, and endemic to the state of Bahia, Brazil (KIERULFF et al., 2008a). In the 1990s some GHLT groups were accidently introduced into an urban Atlantic forest remnant in Niterói, State of Rio de Janeiro, Brazil. The GHLT is considered an exotic and invasive species in this area. Due to the risk of hybridization with local and endangered Leontopithecus rosalia (KIERULFF et al., 2008b), environmental authorities proposed the removal of the GHLT population. Some of the animals captured were translocated to a protected area in southern Bahia while others remained in captivity.

Degradation and fragmentation of habitats foment major contact between humans, domestic, and free-ranging animals. This proximity may affect the ecology of diseases, increasing the transmission of pathogens between these groups (DASZAK et al., 2000; DEEM et al., 2001; COOK \& KARESH, 2008). The Niterói area is fragmented and the GHLT population had been in close contact with humans and domestic animals.

Toxoplasmosis is a worldwide zoonotic disease caused by the protozoan Toxoplasma gondii. Felines are the only known definitive hosts (DUBEY \& BEATTIE, 1988). NWMs are considered highly susceptible whereas the Old World Monkeys are resistant to clinical toxoplasmosis, worldwide reports of T. gondii infection in monkeys have been described (DUBEY \& BEATTIE, 1988; CATÃO-DIAS et al., 2013; DUBEY, 2010). Although there are numerous reports of acute toxoplasmosis in captive monkeys naturally exposed and infected experimentally with T. gondii (DUBEY \& BEATTIE, 1988; DUBEY, 2010), there are few reports of toxoplasmosis in tamarins (PERTZ et al., 1997; EPIPHANIO et al., 2000; EPIPHANIO et al., 2001). Four Golden Lion Tamarins (PERTZ et al., 1997), one Black Lion Tamarin (L. chrysopygus) (EPIPHANIO et al., 2001), and four GHLTs (EPIPHANIO et al., 2000) were maintained in zoos, all died peracutely with few or no clinical signs. T. gondii zoites were identified histologically or by immunohistochemical assays in tissues from necropsied tamarins (PERTZ et al., 1997; EPIPHANIO et al., 2000; EPIPHANIO et al., 2001).

In the present study we investigated the occurrence of $T$. gondii antibodies in a population of exotic invasive GHLT from an urban Atlantic forest in Niterói, RJ/Brazil.

The GHLTs were captured in Serra da Tiririca State Park (22 $2^{\circ} 6^{\prime} 04.28^{\prime \prime}$ S, 4302'22.66"W; Niterói/RJ, Brazil) (Figure 1), a protected area managed by the State Institute of the Environment (INEA) of Rio de Janeiro, as part of a project to remove this introduced

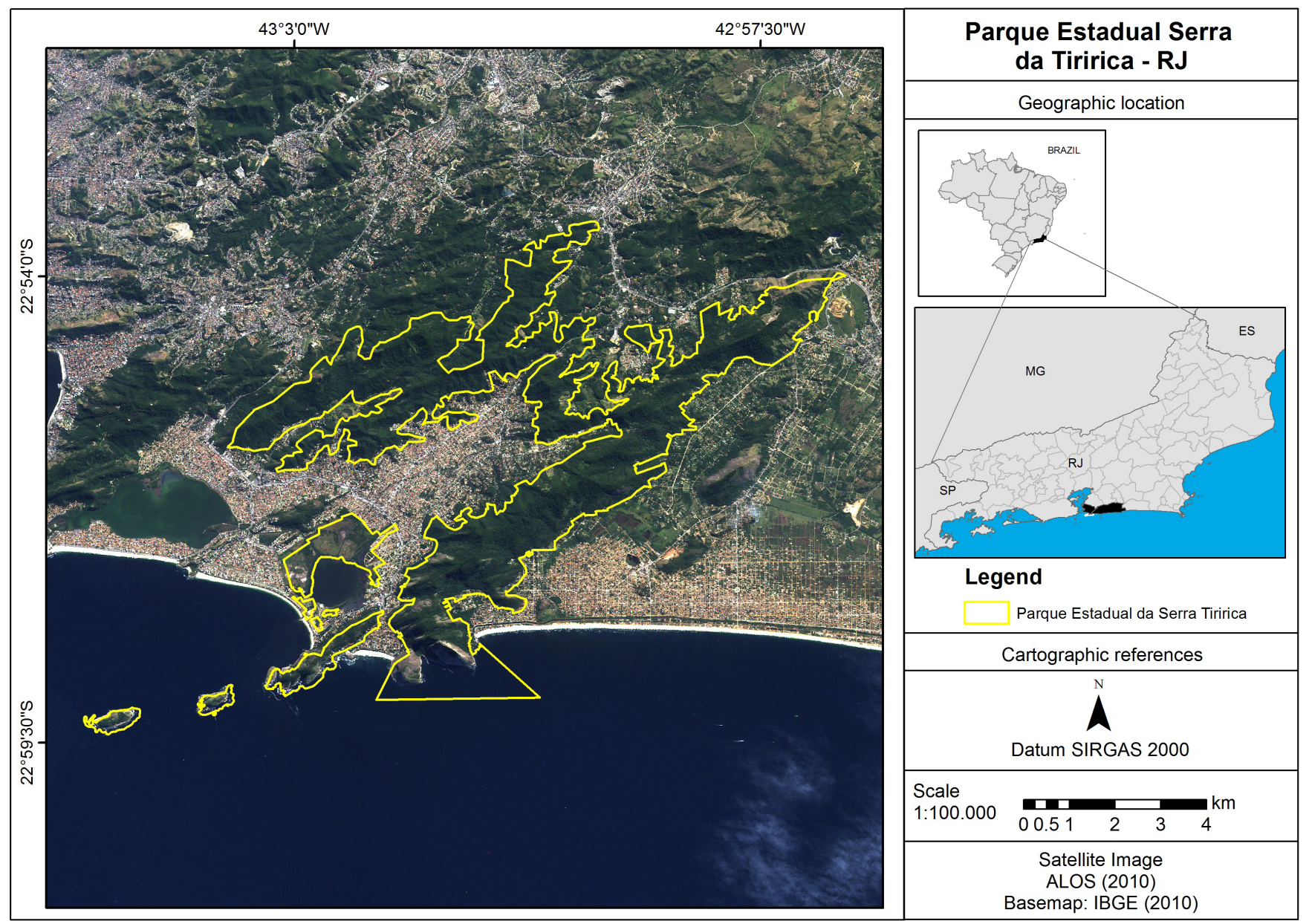

Figure 1. Map of Serra da Tiririca State Park, RJ, Brazil. 
species, administered and conducted by the non-governmental organization Pri-Matas Institute from 2012 to 2015.

These animals were taken to the Primatologic Center of Rio de Janeiro in the municipality of Guapimirim, RJ $\left(22^{\circ} 29^{\prime} 18^{\prime \prime} \mathrm{S}-42^{\circ} 54^{\prime} 53^{\prime \prime} \mathrm{W}\right)$. Chemical restraint for sample collection during quarantine was performed using ketamine $(10 \mathrm{mg} / \mathrm{kg})$ and midazolam hydrochloride $(0.25-0.5 \mathrm{mg} / \mathrm{kg})$.

We tested sera samples from 126 (68 females, 58 males) GHLTs. Ages were not known but 36 were juveniles, 79 were adults, and 11 were elder.

All procedures were approved by the Ethical Principles in Animal Research of the Faculty of Veterinary Medicine and Animal Sciences - University of São Paulo (Protocol number 2662/2012) and were in full compliance with Federal permits issued by the Brazilian Ministry of the Environment (SISBIO 30939-12).

\section{Serology}

The sera were tested for antibodies anti-T. gondii using the Modified Agglutination Test (MAT) (DESMONTS \& REMINGTON, 1980; DUBEY \& DESMONTS, 1987; DUBEY, 2010). The MAT is a highly specific test, both for human and animals. The MAT was validated for human sera using the dye test as the standard (DESMONTS \& REMINGTON, 1980) and is the only serological test that has been validated extensively in many species of animals using the isolation of viable $T$. gondii as the gold standard (DUBEY et al., 1995, 2016; DUBEY, 2010). A detailed procedure for the test was described (DUBEY, 2010) and was followed here. The test does not require species-specific reagents, and controls are sera from animals before and after experimental infection with $T$. gondii. Sera were diluted 1:25, 1:50 and 1:500 with PBS and a MAT cut-off of 1:25 has been used for many species of animals, and humans (DUBEY, 2010).

The introduced GHLTs had close contact with the local human population and domestic animals, often entering homes and digging into garbage. The GHLTs also had close contact with domestic cats that entered the forest areas. In 2003 a study found $24 \%$ of $T$. gondii positive free-ranging cats from urban areas of Niterói, RJ by serological testing (GONÇALVEZ et al., 2003). A serologically positive indicates that the cat has already excreted oocysts in the past (DUBEY, 2010). Thus, it is expected that the GLHTs had some degree of contact with T. gondii oocysts. However, in the present study all 126 sera samples were negative for antibodies anti-T. gondii by MAT in all dilutions tested. We have two possible explanations, one is that the GHLT population did not have contact with T. gondii; second is that animals that had contact with the parasites died before seroconversion. Thus, there are no infected survivors. Our second choice considers the pattern of NWPs-T. gondii interaction, especially Callitrichidae family, which includes the Leontopithecus sp. All animals were apparently healthy at the moment of clinical/veterinarian evaluation.

A study investigated differences in cellular immune response against $T$. gondii using proliferation assays with peripheral blood mononuclear cells (PBMC) from two Sapajus apella and two Leontopithecus chrysomelas. They suggested that the immune system of Sapajus is more able to respond to infection by T. gondii then $L$. chrysomelas, favoring the development of fatal infections (CATÃO-DIAS et al., 2013).

Thereby, serological investigation shows that New World nonhuman primate species apparently exhibit distinct humoral responses against infection by $T$. gondii (CATÁO-DIAS et al., 2013). The prevalence in the Callitrichidae family tends to have lower or zero prevalence, as previous studies has found antibodies anti-T. gondii in captive Callithrix and Leontopithecus (BOUER et al., 2010), and one study in wild Callithrix (MOLINA et al., 2014), showing they are able to seroconvert. These anterior studies and our results may allude to the idea of different responses to different strains.

One hypothesis that explains why NWPs, as Leontopithecus sp, are highly susceptible to toxoplasmosis is that due to their arboreal habits, they had few or no contact with the feline feces in ancestral times, similar to Australian marsupials that evolved without felids (DUBEY, 2010; CATÁO-DIAS et al., 2013). To prevent toxoplasmosis in captive tamarins, animals should be fed only cooked diet and fruits and vegetables should be washed thoroughly to minimize oocyst contamination.

Serological studies in wild population of NWPs are important and generate more data for understanding the relationship between wild primates and pathogens, as $T$. gondii, as well as contribute to the epidemiological knowledge in the different regions. Furthermore, it is crucial to monitor animals in the wild, specially those captured and relocated for species conservation efforts.

\section{Acknowledgements}

We would like to thank Dr. Chris Gardiner and Dr. Jitender Dubey for constructive comments and English review. To Livia Abdalla (Fiocruz, Programa Institucional Biodiversidade e Saúde) for creating the map (Figure 1), and to Fundação de Amparo a Pesquisa do Estado de São Paulo - FAPESP for financial support (number 2015/25760-3).

\section{References}

Bouer A, Werther K, Machado RZ, Nakaghi AC, Epiphanio S, Catão-Dias JL. Detection of anti-Toxoplasma gondii antibodies in experimentally and naturally infected non-human primates by Indirect Fluorescence Assay (IFA) and indirect ELISA. Rev Bras Parasitol Vet 2010; 19(1): 26-31. PMid:20385056. http://dx.doi.org/10.4322/rbpv.01901005.

Catão-Dias JL, Epiphanio S, Kierulff MCM. Neotropical primates and their susceptibility to Toxoplasma gondii: new insights for an old problem. In: Brinkworth JF, Pechenkina K. Primates, pathogens, and evolution, developments in primatology: progress and prospects. New York: Springer Verlag; 2013. p. 253-289.

Cook RA, Karesh WB. Emerging diseases at the interface of people, domestic animals and wildlife. In: Fowler ME, Miller RE. Zoo and wild animal medicine - current therapy. 6th ed. Missouri: Saunders; 2008. p. 55-65.

Daszak P, Cunningham AA, Hyatt AD. Emerging infectious diseases of wildlife - threats to biodiversity and human health. Science 2000; 287(5452): 443-449. PMid:10642539. http://dx.doi.org/10.1126/ science.287.5452.443. 
Deem SL, Karesh WB, Weisman W. Putting theory into practice: wildlife health in conservation. Conserv Biol 2001; 15(5): 1224-1233. http:// dx.doi.org/10.1046/j.1523-1739.2001.00336.x.

Desmonts G, Remington JS. Direct agglutination test for diagnosis of Toxoplasma infection: method for increasing sensitivity and specificity. J Clin Microbiol 1980; 11(6): 562-568. PMid:7000807.

Dubey JP, Beattie CP. Toxoplasmosis of animals and man. Florida: CRC Press; 1988 .

Dubey JP, Desmonts G. Serological responses of equids fed Toxoplasma gondii oocysts. Equine VetJ 1987; 19(4): 337-339. PMid:3622463. http:// dx.doi.org/10.1111/j.2042-3306.1987.tb01426.x.

Dubey JP, Laurin E, Kwowk OCH. Validation of the modified agglutination test for the detection of Toxoplasma gondii in free-range chickens by using cat and mouse bioassay. Parasitology 2016; 143(3): 314-319. PMid:26625933. http://dx.doi.org/10.1017/S0031182015001316.

Dubey JP, Thulliez P, Powell EC. Toxoplasma gondii in Iowa sows: comparison of antibody titers to isolation of $T$. gondii by bioassays in mice and cats. J Parasitol 1995; 81(1): 48-53. PMid:7876977. http:// dx.doi.org/10.2307/3284004.

Dubey JP. Toxoplasmosis of animals and humans. 2nd ed. Florida: CRC Press; 2010

Epiphanio S, Guimarães MA, Fedullo DL, Correa SH, Catão-Dias JL. Toxoplasmosis in golden-headed lion tamarins (Leontopithecus chrysomelas) and emperor marmosets (Saguinus imperator) in captivity. JZoo Wildl Med
2000; 31(2): 231-235. PMid:10982139. http://dx.doi.org/10.1638/10427260(2000)031[0231:TIGHLT]2.0.CO;2.

Epiphanio S, Sa LRM, Catão-Dias JL, Teixeira RHF. Toxoplasmosis in a wild-caught black lion tamarin (Leontopithecus chrysopygus). Vet Rec 2001; 149(20): 627-628. PMid:11761297. http://dx.doi.org/10.1136/ vr.149.20.627.

Gonçalvez E No, Munhoz AD, Albuquerque GR, Lopes CWG, Ferreira AMR. Ocorrência de gatos soropositivos para Toxoplasma gondii Nicolle e Manceaux, 1909 (Apicomplexa: Toxoplasmatinae) na cidade de Niterói, Rio de Janeiro. Rev Bras Parasitol Vet 2003; 12(4): 145-149.

Kierulff MCM, Rylands AB, Mendes SL, Oliveira MM. Leontopithecus chrysomelas. In: International Union for Conservation of Nature-IUCN. The IUCN Red List of Threatened Species [online]. Version 2015.2. 2008a [cited 2015 July 30]. Available from: www.iucnredlist.org

Kierulff MCM, Rylands AB, Oliveira MM. Leontopithecus rosalia. In: International Union for Conservation of Nature-IUCN. The IUCN Red List of Threatened Species [online]. Version 2015.2. 2008b [cited 2015 July 30]. Available from: www.iucnredlist.org

Molina CV, Catão-Dias JL, Ferreira JS No, Vasconcellos SA, Gennari SM, Valle RR, et al. Sero-epidemiological survey for brucellosis, leptospirosis, and toxoplasmosis in free-ranging Alouatta caraya and Callithrix penicillata from São Paulo State, Brazil. J Med Primatol 2014; 43(3): 197-201. PMid:24646216. http://dx.doi.org/10.1111/jmp.12112.

Pertz C, Dubielziq RR, Lindsay DS. Fatal Toxoplasma gondii infection in golden lion tamarins (Leontopithecus rosalia rosalia). J Zoo Wildl Med 1997; 28(4): 491-493. PMid:9523646. 